\title{
Stimulating Curiosity and Consumer Experience in a Retailer
}

\author{
Silvia Cachero-Martínez, Rodolfo Vázquez-Casielles \\ University of Oviedo, Oviedo, Spain \\ Email: cacherosilvia@uniovi.es,rvazquez@uniovi.es
}

How to cite this paper: Cachero-Martínez, S. and Vázquez-Casielles, R. (2017) Stimulating Curiosity and Consumer Experience in a Retailer. American Journal of Industrial and Business Management, 7, 473-486. https://doi.org/10.4236/ajibm.2017.74034

Received: February 16, 2017

Accepted: April 25, 2017

Published: April 28, 2017

Copyright $\odot 2017$ by authors and Scientific Research Publishing Inc. This work is licensed under the Creative Commons Attribution International License (CC BY 4.0).

http://creativecommons.org/licenses/by/4.0/

\section{Open Access}

\begin{abstract}
Nowadays, retailers have to try to differentiate themselves from their competitors through consumer shopping experience. The authors distinguish several experience dimensions and develop a shopping experience scale that includes six dimensions: sensory (tactile, scent, auditory, visual, taste), intellectual (through design and with employees), social, pragmatic and emotional. Analyzing the experiences by sectors of activity, our study indicates that the emotional experience predominates in some sectors, like jewelry or bookstores. Emotional experience can also be linked to pragmatic experience. This occurs in the sports, decoration and toy sectors. Thus it is important to develop innovations related to emotional experience. Enhancing imagination, creativity and arousing consumer curiosity the retailer will create an experiential shop, which are of particular interest to the consumer.
\end{abstract}

\section{Keywords}

Experience Marketing, Emotion, Retail, Customer Experience Management

\section{Experiences and Emotions in Consumer Behavior}

Nowadays shopping experience plays an important role in consumer behavior that is why both academic experts and retailers pay special attention to it [1] [2] [3]. When customers visit and shop in a retailer, they may want different experiences that surprise them. Therefore, retailers should control key determinants of customer experience dimensions for successful management of their store. Customer's surprise, resulting from the experiences in the store, can cause different emotions (e.g. happy, hopeful, entertaining, animated and/or enthusiastic). These positive emotions affect shopping time, willingness to pay more for the same product and loyalty to the retailer. Also, positive emotions converge on memorability, and the perceptions of a company's image are enhanced, stimu- 
lating purchases and generate close and lasting relationships with the brand [4].

There are several studies on consumer experience [5] [6] [7], which refer to brand experiences [8], not to consumer experiences in a retailer. Therefore, retail managers still need methods and procedures that show them what they can offer in experience marketing. In this sense, this paper presents an important distinction between experiences for retailers who are interested in the experience economy. The study defines and conceptualizes the shopping experience construct. We begin with a review of the literature in consumer and marketing experience research, which analyzes when each type of experience occurs and how it affects consumer behavior. Next, we review the literature in consumer experience scale, and propose our own scale based on the literature. Later, we obtain the perception of different retailer sectors in each of the experience dimensions. Finally, from what is known, we highlight key insights, theoretical contributions and management implications for marketing practice.

\section{Designing Experiences}

Customer experience depends not only on the aspects which retailers can control (store design, quality of service, promotion...), but also on factors that are outside of the retailer's control (relationship with other consumer, shopping motivations...) [9] [10]. However, marketing literature has identified different consumer experience dimensions. These experiences are the stimulus that enables the customer to have the desired experiences. This stimulus can be controlled by marketing managers to design the retail atmosphere. The literature review shows evidence that the consumer shopping experience can be divided into several dimensions [3] [5] [6] [9] [11] [12] [13] [14] [15]. In our research, we have identified four dimensions of experience that a retailer can modify: sensory, intellectual, social and pragmatic. Also, we recognized that emotional experience is defined by the affective state of the consumer, so it's more subjective and it only depends on the consumer opinion.

\subsection{Emotional Experience}

Academics have recognized that an important dimension of experience construction is the emotions (e.g. happiness, enjoyment, entertainment). Buying goods and services, the consumer wants to accomplish emotional experiences. Therefore, marketing literature advocates greater attention to hedonic consumption and the myriad ways in which consumers seek emotions [16].

The informational value of emotions is used by the consumer as a heuristic decision: I feel good (happy, entertained) with the experience (sensory, intellectual, social) that the retailer provides, proceeding to the purchase or the recommendation of that store [17]. It is an emotional state of people, accompanied by subjective reaction and influenced by experience, which provides hedonic value and satisfaction [18]. Emotions arising from shopping experiences deposit affective memory traces, which consumers process and integrate to form post-shopping satisfaction [19]. 
Emotions may be classified as positive or negative [20]. This distinction refers to whether a stimulus can promote or obstruct a certain objective [21]. The retailer should create positive emotional experiences, because the consumer tends to seek positive emotions and avoid negative ones [22]. If the consumer gets excited about a store, he will try to relive the same experience in order to maintain or increase the resulting positive emotional state [23].

\subsection{Antecedents of Emotional Experience}

Marketing literature has identified different consumer experience dimensions, which can be determinants of emotional experience. Schmitt [24] indicates that there is a hierarchy structure of these experiences. This sequence is also consistent with the cognitive-affective-conative structure [25]. From marketing literature, we believe that consumer experience is a multidimensional concept, analyzed in the following sub-sections its four dimensions.

\subsubsection{Sensory Experience}

The Sensory Marketing is defined as "marketing that engages the consumer's senses and affects their perceptions, judgments and behaviors" [4]. Retail atmosphere literature has identified experiences that customers perceive by the senses of somatosensation, olfaction, hearing, sight and taste [26]. These sensory experiences are caused in retail environments by a variety of stimuli [27] [28].

\section{1) Tactile experience}

The role of touch in marketing is least studied, but researchers are now saying it can be a deal breaker. Customers have experiences every time they "touch" any part of the product, service, brand or organization, at various points in time [10]. In this research, we only study touching experience with products. In this sense, touching experience research identifies two types of touch [29]: instrumental touch and hedonic touch. The first type accepts that the consumer is involved in touch as a means to an end (e.g. touching a product only to make a purchase, touching to obtain non-haptic product information, touching to obtain haptic product information). In contrast, in hedonic touch, touch is an end by itself. An example of "falling in love" through tactile experience are Apple Stores, where the consumer interacts with the product to see all its features. These stores set their notebook computers at 70 degrees, open enough to tease but not to view the content, to entice customers to touch and flip the screen to its viewing angle. The company creates experiences based on the handling of products, so that customer perceptions activate positive emotional experience.

\section{2) Scent experience}

Our olfactory bulb that processes scent is linked to our brain's limbic system, which processes emotions and memories, the most important factors that affect our shopping behavior. Scent marketing allows the retailer to use the scents to provoke moods, to position a brand or to promote products [30]. Perhaps the greatest growth in scent marketing in recent years has taken place with regard to the use of ambient scent, which is emitting scents into retail store atmospheres 
as an element of the environment. Ambient scent is believed to have the potential to create positive emotions and satisfaction [31]. The literature on scent experience allows the establishing of the characteristics of smell [30]: a) Preferences for smells are learned; b) Odor processing is slow but persistent; and c) Odor active perception and memory and has the potential to create positive emotional responses (emotions) as well as a more favorable assessment of a retailer. For example, Bloomingdale's uses different scents in different departments to elicit different emotions: coconut in swimwear for a tropical paradise feel, lilac in lingerie for a sensual appeal and baby powder in infant wear. Another example is Hugo Boss, which uses a musky smell with a citrus hint in all its stores as a signature memory trigger. Even with eyes closed, shoppers can tell they're in a Hugo Boss shop.

\section{3) Auditory experience}

Music can positively influence emotions, information processing and satisfaction [32], so retailers use music intentionally to develop shopping experience in stores. Such research focuses on three aspects: tempo, type and volume [4] [33]. Music tempo in stores is often connected with the relaxing of shopping and emotional experience (e.g. happiness, joy, entertainment). Slow tempo music calms consumers and fast tempo music can generate situations of auditory arousal. Music type is also important, because it is a tool that connects stores with similar target customers and reinforces satisfaction, and brand characteristics. For example, when a store plays classical music customers say that this store was a sophisticated image, however when it plays pop music it turned into a fun, lively and upbeat place. Finally, music volume also stimulates shopping and their satisfaction and shopping behavior. For example, Abercrombie \& Fitch often play music in high volume to attract young people to the store. Another example is Victoria's Secret, with a soothing music that facilitates talking with sales staff.

\section{4) Visual experience}

There are three different constructs that affect consumer's visual cues [34]: attention, imagery, and neural activation. These constructs produce a diversity of reactions, as well as emotions and satisfaction [35]. It is the most direct way to provide information to customers and attract them to the store. Real examples of visual experience are $M \& M$ stores, which have become a tourist destination for tourists visiting cities where it operates: Las Vegas, New York, Orlando, London and Shanghai. M \& M store in New York City has a machine that scans consumer's body and tells them what M \& M chocolate color belongs to them. The most studied factors are the impact of color and retail lighting on consumer behavior. Warm colors are suitable to attract impulsive buyers and it produces more attraction to the store, evoking emotions associated with states of cheerful mood, vitality, higher levels of distraction. On the other hand, cool colors are for customers with a buying plan and are associated with affective states such as a peace, calm and happiness [36]. Thus, the color blue, which reflects calm, relaxation and tranquility, can stimulate consumer creativity while the color red, which reflects stimulation and arousal, can facilitate analytical skills. 


\section{5) Taste experience}

Taste experience is affected by our senses of auditory, vision, touch, and particularly scent [4]. So, taste experience research affirms that taste is understood as a combination of all our senses. Visual and scent-based cues play such an integral role in taste that they sometimes take priority over cues from the taste buds. This means that retailers dealing with food and beverage products can gain an advantage by appealing strongly to the other senses, generating emotions and achieving satisfaction. An example of taste experience is Savannah Taste Experience Food Tours, which are 3-hour walking and tasting tours where you will enjoy a fun, one-of-a-kind culinary experience while strolling through the gardens and historic, cultural landmarks of the squares of Savannah, the Hostess City of the South.

\section{6) Multisensory experience}

Information is perceived and processed in multiple sensory modalities [37]. Recognizing this multi-sensory aspect, a rich stream of research has emerged on multisensory customer experiences, analyzing interplay between senses. For example, inter-sensory effects between taste and vision [38], taste and touch [39], touch and vision [33] [40] and taste and sound [41] have begun to be explored. According to these investigations, retailers can make their stores more attractive via multi-sensory experiences to elicit emotions or to emphasize satisfaction.

\subsubsection{Intellectual Experience}

Intellectual experiences are experiences associated to thinking and conscious mental processes to get consumers to use their imagination or problem solving so that they review suppositions about a product. This type of experience occurs when the retailer's merchandising strategy (intellectual experience through design) and/or communication with employees (intellectual experience with employees) help to inspire customer curiosity and invite them to think and to imagine [42]. Curiosity is the motivating state among consumers when a marketer evokes mystery [43]. Researchers supporting that curiosity causes positive results for retailer [44]. For example, Apple Store shows its products and allows consumers to interact with them. An interesting tool for retailers is augmented reality [45], which will have an important development in the near future [46]. It's the practice of augmenting a real-time direct or indirect view of the real physical world with virtual information [47]. For example, IKEA could help consumers visualize how a new closet might look next to their existing furniture.

When intellectual experiences happen, they result in different types of creative thinking such as convergent and divergent thinking [5] [48]. Convergent thinking entails using heuristics (rules of thumb) to make a decision, induce the consumers thinking to move along a planned sequence [24].

Divergent thinking involves educating and teaching consumers to develop some originality in different and creative ways. Divergent thinking is an activity contained in another function of the mind called the imagination. By imagining, consumers create something new, something they had never seen in the same 
terms, reviewing their idea about a product or service and the mental assumptions commonly accepted with it. Therefore, the offer of original and creative activities involves a greater diversity of experience and satisfaction.

\subsubsection{Social Experience}

Social experience implicates the consumer and his/her social environment, his/her relationship with other consumers and also with his/her ideal self [49]. A retailer can develop this dimension of experience with different strategies that allow consumers to enjoy themselves during their shopping time. For example, a) go shopping with family/friends and get information about new products or trends that reflect attitudes and lifestyles; b) opportunity to interact with other customers who share interests; c) go shopping to belong to a social identity, inducing a sense of belonging or the distinction from a social group. Sales staffs are fundamental in providing positive customer experiences. For example, Sisley organized in Bloomingdale's store, in New York, a test of its new products. This encourages interaction with people with similar interests.

\subsubsection{Pragmatic Experience}

Pragmatic experience is an experience resulting from the utilitarian activity of the retailer [50]. It is a desired experience for those consumers who value functionality, utility, monetary value and who do not pay attention to the aesthetics, design or social context in which the purchase takes place. This consumer is not a shopper who is guided by his emotions The retailer can encourage this pragmatic experience offering an assortment of products and brands with good quality and an interesting price level and consumer promotions. For example, Decathlon is known for its aggressive pricing policy on sales periods. Moreover, its own brands are particularly relevant in assortment management.

Sometimes pragmatic experience can be affected by emotions. In this case, consumers believe that a utilitarian purchase can be pleasurable for a number of non-monetary and/or entertainment reasons, or even the simple emotion of getting a good deal [16].

\section{Research Method}

\subsection{Developing a Measure of Customer Experience}

Experience dimensions were measured with various items. To develop these items, five information sources were used. First, we reviewed experience and emotions research. Secondly, we visited retailers from various sectors in Spain, with business strategies related to shopping experience dimensions. Thirdly, we interviewed consumers to tell us an experience that they remembered from the retail sectors that we wanted to study. With all this information, we developed a preliminary scale that represents five experience dimensions: emotional, sensory, intellectual, social, and pragmatic. Fourthly, we conducted in-depth interviews with ten consumers and a panel of experts (three retail managers and six expert researchers in retailing). The retail experts proposed us to divide intellectual experience into two dimensions: one through design and the other with employees. 
Finally, we performed a pre-test of measurement scales on experience dimensions. Personal interviews were conducted to a sample of thirty retailer-loyal consumers with experience in marketing strategies. The results allowed us to understand the measurement scales, removing ambiguous items or modifying wording to facilitate interpretation (see measurement scale in Table 1). The resulting measurement scale comprises six experience dimensions with 36 corresponding items. Each item was measured with likert scales ("1-Strongly Disagree" to "7-Strongly Agree"). In the case of emotional experience, it was measured as the intensity of emotions ("1-Not at All" to "7-Completely").

Table 1. Measurement scales.

\section{Sensory experience}

Temperature is suitable, activating shopping experience

Cleanliness and good condition stimulates shopping experience

Lighting is motivating, making shopping experience pleasant

Color of walls and floor provide a shopping experience in a pleasant environment

Music (tempo, volume and type) provides a very pleasant shopping experience

Smells provides a very pleasant shopping experience

Intellectual experience (through design)

Design (furniture, decor and equipment) stimulates curiosity

Sections design stimulates shopping experience and interacting with the product

Communication materials (display) stimulates imagination, thought and creativity consumer

Store layout stimulates curiosity

Shop-window offers an attractive presentation (suggestive, artistic, creative)

Store has a pleasant entry (spacious and inviting)

Outside of store design invites you to enter

Intellectual experience (with employees)

Employees are always willing to help (provide information, support to decision-making) and answer all questions

Employees have great knowledge of what they sell and the experiences that the products provide

There are enough employees to offer personalized service and explain the experiences provided by the use of products

Payment for items purchased is fast avoiding negative experiences

\section{Social experience}

Shopping at this store give me the opportunity to experience feeling of status (interact with other customers)

Shopping at this store allows me to get information and experiences on trends consistent with my attitudes and lifestyles

Go to this store allows me to spend a pleasant time with my family/friends

\section{Pragmatic experience}

Brands offered are known and good quality

Product assortment is sufficient to meet my needs

Periodically updates its assortment incorporating the latest product version

In this store I get quality products at a good price

Compared with other competitors this store offers the best price-quality

This store offers a variety of services (warranty, product returns, home delivery, packaging for a gift) with good prices

It offers better promotions than competition

Consumer information about promotions is very suitable

Always have stock of products on promotion

In promotional periods product quality is maintained

\section{Emotional experience (intensity of emotions)}

Happy (joyful, contented)

Hopeful

Entertaining

Animated (encouraged)

Enthusiastic

Surprised 


\subsection{Sample Description}

Subsequently we conducted a field survey to assess customer opinions on experience dimensions. We used personal surveys on the street and online surveys. The sample consisted of 527 people from several cities in Spain. To be part of the sample the consumers had to shop in one of the indicated sectors in the last three months. In this way, consumers were invited to think and remember that shopping experience. The sample distribution was done by age (65\% between 18 and 44 years and $35 \%$ over 45 years) and gender ( $43 \%$ male). Nine sectors were analyzed and the sample distribution is: clothing stores and fashion (44\%); shoes (7.2\%); cosmetics and perfumery (9\%); jewelry (3.4\%); sports (9.3\%); computing and electronics (8.7\%); decoration (6.6\%); bookstores (9.1\%) and toys (2.7\%).

\subsection{Validity and Reliability of the Measurement Scale}

Confirmatory Factor Analysis (CFA) was applied to evaluate validity and reliability of the measurement scale [51]. EQS 6.2 was used to do this CFA. The overall fit of the measurement scale is good (BBNNFI $=0.855$; CFI $=0.906$; RMSEA $=0.044)$. All items were significant $(\mathrm{p}<0.001)$ and considerable on their respective theoretical concepts. Cronbach's alpha coefficient was greater than 0.7 , the composite reliability was greater than 0.7 and the Average Variance Extracted (AVE) was greater than 0.5 .

\section{Results on Perception of Retailers for Each Experience Dimension}

Once the validity and reliability of the measurement scale is checked, we proceed to estimate the perception of each experience dimension as an average of the attributes that define them. In this way we obtain different results derived from the evaluation of the different retail sectors analyzed by type of experience (Figure 1). The emotional experience is mainly present in jewelry, sports, decoration, bookshop and toy sectors. The sensory experience is typical of the sectors of clothing stores and fashion, cosmetics and perfumery and bookstore. In bookstore sector, all consumer experience modalities predominate (except pragmatic experience), as well as in the sports sector (except the sensory dimension) and in the cosmetic and perfumery sector (except the emotional experience). Shoe sectors are perceived as establishments offering a pragmatic experience and intellectual experience with employees. In computer and electronics sector, the pragmatic experience is the most relevant. The intellectual experience through design is observed in the following sectors: sports, decoration, bookshop, cosmetics and perfumery and clothing stores and fashion. The social experience is observed in clothing stores and fashion, sports, bookstore and cosmetics and perfumery.

\section{Discussion}

\subsection{Theorical Contributions}

Today's consumer seeks to spend a fun shopping time away from the daily 

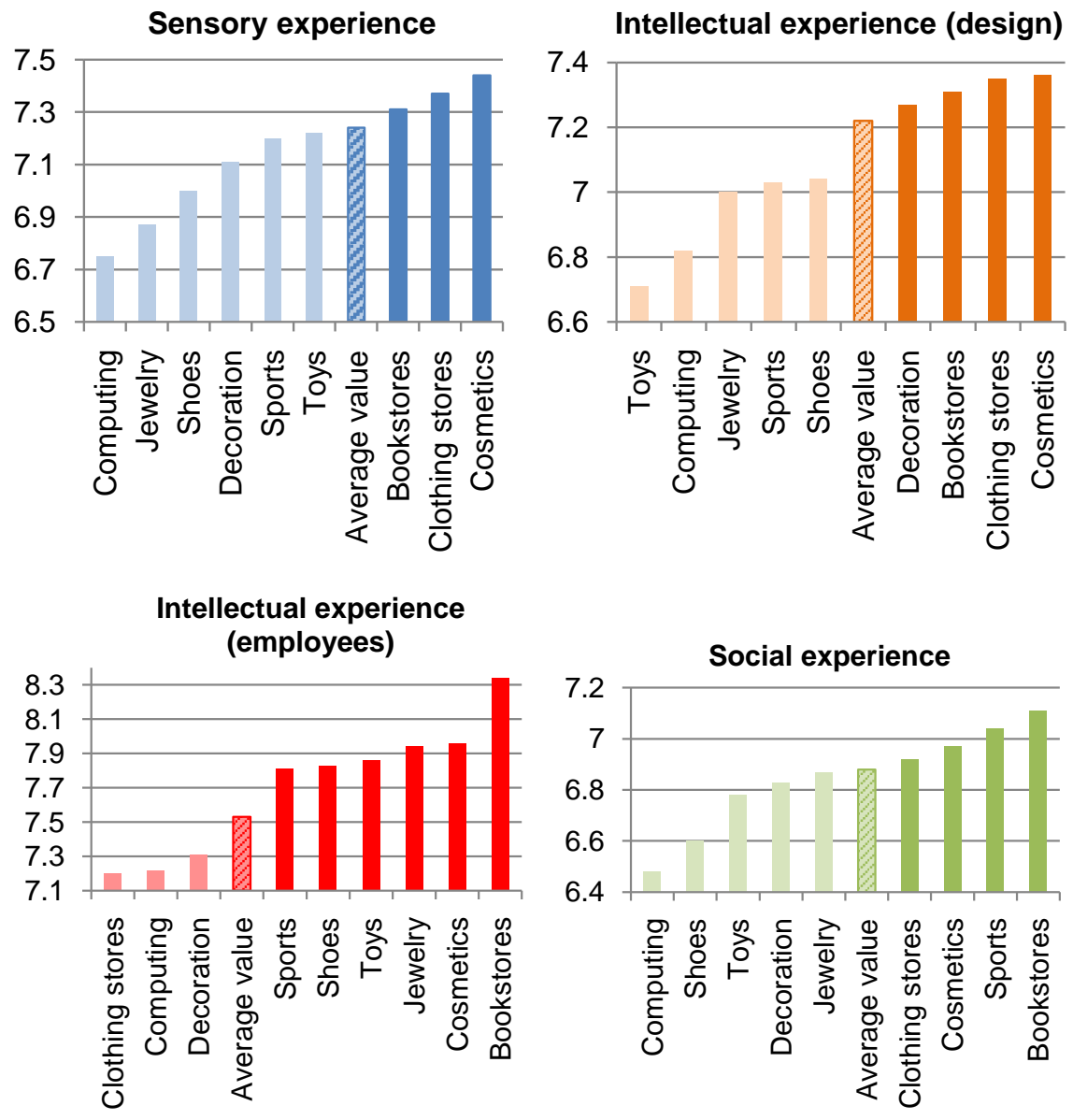

Pragmatic experience
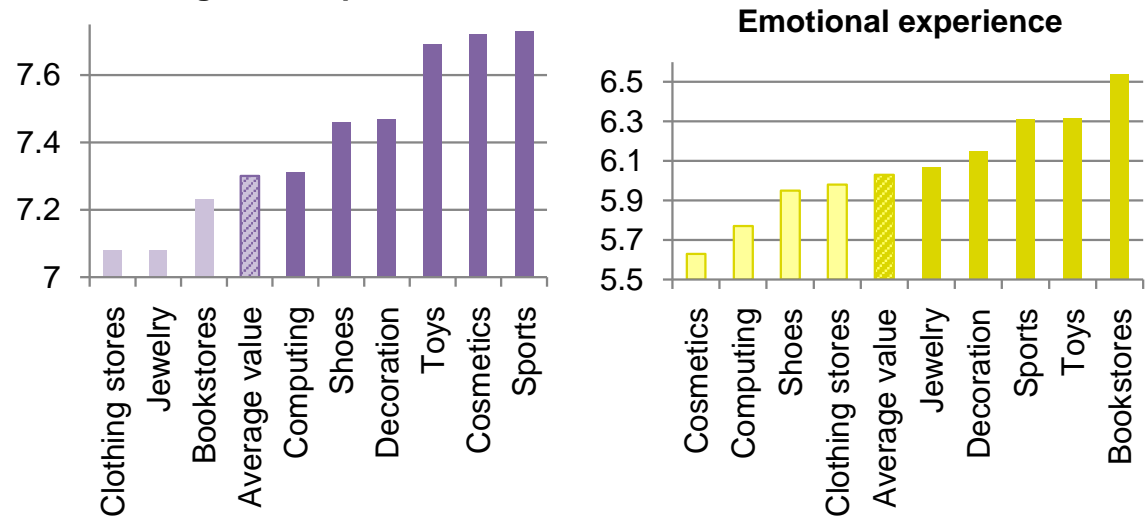

Figure 1. Main results of the survey.

routine. The retailers get this through the creation of shopping experiences. A unique and unrepeatable process of shopping leads retailers to create a strong emotional bond with the consumer. The main objective of this research was to analyze consumer experience dimensions when they shop offline. This research makes several contributions to the literature.

This study provides evidence that the generation of experiences involves the presence of more than one dimension. Our study identified five categories: sensory, intellectual, social, emotional and pragmatic experience. Our main effort 
was to design a scale to measure multidimensional experience. Retail experts contributions suggested we divide the intellectual experience into two dimensions, which was confirmed by the validity scale of measurement proposed later.

Analyzing the experiences by sectors of activity, the emotional experience predominates in some sectors, like jewelry or bookstore. These sectors are related to hedonic consumption and shopping pleasure, since in both cases they are products that are not of first necessity. In contrast, the pragmatic experience predominates in the shoes, cosmetics and perfumery and computing and electronics sector, which are more linked to the functionality of their products. As discussed previously, emotions can also be linked to pragmatic experience. This occurs in the sport, decoration and toy sectors, where both pragmatic experience and emotional experience are present. They are sectors where the consumer enjoys shopping at a good price, or with the non-monetary promotions they offer.

\subsection{Management Implications}

This article assumes the starting point from which retailers interested in marketing experiences should base their strategies. First of all, the retailer must encourage the type of experience that the consumers want according to their sector of activity. For example, retailers in the footwear sector should pay attention to utilitarian attributes of product assortment. It includes decisions on quality of products, price level and promotions.

Second, experience literature shows that it is very important to develop innovations related to experiences that generate emotions. Stimulating consumer curiosity, imagination and creativity in store can cause positive emotions. An important new tool to help retailers to do this is augmented reality. For example, Acustom Apparel Shop in Soho have a three-dimensional scanner body, and customers can choose fabrics, color... to make a suit, a shirt, jeans or a tailored suits with their measures.

Positive emotions can be completed with other experiences, as intellectual experience. For example, using a pleasantly designed store (furniture, decoration and equipment) to facilitate product display, arouse consumer curiosity, and invite the product test.

Furthermore, offering a complete experience through technology retail 3.0, with employees specially trained to offer a customized service, guidance to customers and help them to understand, enjoy and be creative with new products or services. The goal is that consumers perceive the buying process as an experience that allows them to analyze, together with others, the assortment of products from the store, socialize and access information offered by the retailer through social networks.

This study strengthens the idea that the consumer is a social being. For him, the experience that he gets from interacting with other consumers and with store employees is important. These interactions can go beyond, and take place in other environments like the online world. Retailers can benefit from these social experiences online if they know how to manage them. 
Retailers should not forget the utilitarian attributes of their offer. Furthermore, retailers should have a mix of brands: manufacturer's brand and store brand. Manufacturer's brand can attract consumer to the store, but private labels can turn customer into fans.

Finally, retailers must not forget sensory experience perceived through senses. In a store all decisions affect, in one way or another, sensory perception: store lighting, smells, music, placement of products... This perception can complement the other experience dimensions, thereby helping to increase satisfaction. The retailer must pay attention to monitoring lighting, hedonic touch (where touch is an end by itself, a desirable experience, not essentially informative), music (tempo, volume and type) and smells that offer a very enjoyable shopping experience. A good example is "Starbucks Experience" and its aroma. The smells are so important that in 2008 they eliminated hot sandwiches from their assortment because it interfered with the coffee aroma. Feeling the brand through smell is essential for creating a consumer experience, establishing a closer relationship with the consumer.

Companies need to do more than just offer a good product or a good location; it's not enough for success in retailing. Given the current competitive intensity they have to differentiate themselves from their competitors, and managing customer experiences offers a great opportunity to do this.

\section{Acknowledgements}

The authors are grateful to Cátedra Fundación Ramón Areces de Distribución Comercial (www.catedrafundacionarecesdcuniovi.es) for their valuable support to develop this empirical research.

\section{References}

[1] Beltagui, A., Candi, M. and Riedel, J.C.K.H. (2016) Setting the Stage for Service Experience: Design Strategies for Functional Services. Journal of Service Management, 27, 751-772. https://doi.org/10.1108/JOSM-08-2015-0234

[2] Lemon, K.N. and Verhoef, P.C. (2016) Understanding Customer Experience throughout the Customer Journey. Journal of Marketing, 80, 69-96.

https://doi.org/10.1509/jm.15.0420

[3] Srivastava, M. and Kaul, D. (2016) Exploring the Link between Customer Experience-Loyalty-Consumer Spend. Journal of Retailing and Consumer Services, 31, 277-286. https://doi.org/10.1016/j.jretconser.2016.04.009

[4] Krishna, A. (2013) Customer Sense. How the 5 Senses Influence Buying Behavior. Palgrave MacMillan, New York.

[5] Brakus, J.J., Schmitt, B.H. and Zarantonello, L. (2009) Brand Experience: What Is It? How Is It Measured? Does It Affect Loyalty? Journal of Marketing, 73, 52-68. https://doi.org/10.1509/jmkg.73.3.52

[6] Gentile, C., Spiller, N. and Noci, G. (2007) How to Sustain the Customer Experience: An Overview of Experience Components That Co-Create Value with the Customer. European Management Journal, 25, 395-410. https://doi.org/10.1016/j.emj.2007.08.005

[7] Schmitt, B.H. (2003) Customer Experience Management. A Revolutionary Ap- 
proach to Connecting with Your Customer. John Wiley \& Sons, New York.

[8] Moreira, A.C., Fortes, N. and Santiago, R. (2017) Influence of Sensory Stimuli on Brand Experience, Brand Equity and Purchase Intention. Journal of Business Economics and Management, 18, 68-83. https://doi.org/10.3846/16111699.2016.1252793

[9] Verhoef, P.C., Lemon, K.N., Parasuraman, A., Roggeveen, A., Tsiros, M. and Schlesinger, L.A. (2009) Customer Experience Creation: Determinants, Dynamics and Management Strategies. Journal of Retailing, 85, 31-41. https://doi.org/10.1016/j.jretai.2008.11.001

[10] Stein, A. and Ramaseshan, B. (2016) Towards the Identification of Customer Experience Touch Point Elements. Journal of Retailing and Consumer Services, 30, 8-19. https://doi.org/10.1016/j.jretconser.2015.12.001

[11] Yang, Z.Y. and He, L.Y. (2011) Goal, Customer Experience and Purchase Intention in a Retail Context in China: An empirical Study. African Journal of Business Management, 5, 6738-6746.

[12] Srivastava, M. and Kaul, D. (2014) Social Interaction, Convenience and Customer Satisfaction: The Mediating Effect of Customer Experience. Journal of Retailing and Consumer Services, 21, 1028-1037. https://doi.org/10.1016/j.jretconser.2014.04.007

[13] Schmitt, B., Brakus, J.J. and Zarantonello, L. (2015) From Experiential Psychology to Consumer Experience. Journal of Consumer Psychology, 25, 166-171. https://doi.org/10.1016/j.jcps.2014.09.001

[14] Verleye, K. (2015) The Co-Creation Experience from the Customer Perspective: Its Measurement and Determinants. Journal of Service Management, 26, 321-342. https://doi.org/10.1108/JOSM-09-2014-0254

[15] Bhandari, S. (2016) Customer Experience: An Emerging Source of Sustainable Competitive Advantage. Imperial Journal of Interdisciplinary Research, 2, 245-254.

[16] Alba, J.W. and William, E.F. (2013) Pleasure Principles: A Review of Research on Hedonic Consumption. Journal of Consumer Psychology, 23, 2-18. https://doi.org/10.1016/j.jcps.2012.07.003

[17] MacInnis, D.J. and de Mello, G.E. (2005) The Concept of Hope and Its Relevance to Product Evaluation and Choice. Journal of Marketing, 69, 1-14. https://doi.org/10.1509/jmkg.69.1.1.55513

[18] Pullman, M.E. and Gross, M.A. (2004) Ability of Experience Design Elements to Elicit Emotions and Loyalty Behaviors. Decision Sciences, 35, 551-578. https://doi.org/10.1111/j.0011-7315.2004.02611.x

[19] Machleit, K.A. and Eroglu, S.A. (2000) Describing and Measuring Emotional Response to Shopping Experience. Journal of Business Research, 49, 101-111. https://doi.org/10.1016/S0148-2963(99)00007-7

[20] Weiner, B. (1985) An Attributional Theory of Achievement Motivation and Emotion. Psychological Review, 92, 548-573. https://doi.org/10.1037/0033-295X.92.4.548

[21] Scherer, K.R. (1988) Criteria for Emotion-Antecedent Appraisal: A Review. In: Hamilton, V., Bower, G.H. and Frijda, N.H., Eds., Cognitive Perspectives on Emotion and Motivation Dordrecht, Kluwer, The Netherlands, 89-126. https://doi.org/10.1007/978-94-009-2792-6_4

[22] Maio, G.R. and Esses, V.M. (2001) The Need for Affect: Individual Differences in the Need to Approach or Avoid Emotion. Journal of Personality, 69, 583-614. https://doi.org/10.1111/1467-6494.694156

[23] Troilo, G., Cito, M.C. and Soscia, I. (2014) Repurchase Behavior in the Performing Arts: Do Emotions Matter without Involvement? Psychology \& Marketing, 31, 635- 
646. https://doi.org/10.1002/mar.20724

[24] Schmitt, B.H. (1999) Experiential Marketing. How to Get Customers to Sense, Feel, Think, Act, Relate to Your Company and Brands. The Free Press, New York.

[25] Ajzen I. and Fishbein, M. (1980) Understanding Attitudes and Predicting Social Behavior. Prentice Hall, Upper Saddle River.

[26] Möller, J. and Herm, S. (2013) Shaping Retail Brand Personality Perceptions by Bodily Experiences. Journal of Retailing, 89, 438-446.

https://doi.org/10.1016/j.jretai.2013.05.004

[27] Grewal, D., Levy, M. and Kumar, V. (2009) Customer Experience Management in Retailing: an Organizing Framework. Journal of Retailing, 85, 1-14. https://doi.org/10.1016/j.jretai.2009.01.001

[28] Helkkula, A. (2011) Characterizing the Concept of Service Experience. Journal of Service Management, 22, 367-389. https://doi.org/10.1108/09564231111136872

[29] Peck, J. (2010) Does Touch Matter? Insights from Haptic Research in Marketing. In: Krishna, A., Ed., Sensory Marketing. Research on the Sensuality of Products, Routledge, New York, 17-31.

[30] Morrin, M. (2010) Scent Marketing. An Overview. In: Krishna, A., Ed., Sensory Marketing. Research on the Sensuality of Products, Routledge, New York, 75-86.

[31] Herz, J. (2007) The Scent of Desire. Discovering Our Enigmatic Sense of Smell. William Morrow, New York.

[32] Mattila, A.S. and Wirtz, J. (2001) Congruency of Scent and Music as a Driver of in-Store Evaluations and Behavior. Journal of Retailing, 77, 273-289.

https://doi.org/10.1016/S0022-4359(01)00042-2

[33] Krishna, A. (2010) Sensory Marketing. Research on the Sensuality of Products. Routledge, New York.

[34] Raghubir, P. (2010) Visual Perception: An Overview. In: Krishna, A., Ed., Sensory Marketing. Research on the Sensuality of Products, Routledge, New York, 201-207.

[35] Labrecque, L. and Milne, G. (2011) Exciting Red and Competent Blue: The Importance of Color in Marketing. Journal of the Academy of Marketing Science, 40, 711727. https://doi.org/10.1007/s11747-010-0245-y

[36] Gómez, M. and García, C. (2010) Nuevas Tendencias en el Punto de Venta: el Marketing Sensorial. In: Cátedra Fundación Ramón Areces de Distribución Comercial, Universidad de Oviedo, Eds., Distribución Comercial y Comportamiento del Consumidor, 235-247.

[37] Spence, C. and Gallace, A. (2011) Multisensory Design: Reaching Out to Touch the Consumer. Psychology and Marketing, 28, 267-307. https://doi.org/10.1002/mar.20392

[38] Hoegg, J. and Alba, J.W. (2007) Taste Perception: More than Meets the Tongue. Journal of Consumer Research, 33, 490-498. https://doi.org/10.1086/510222

[39] Krishna, A. and Morris, M. (2008) Does Touch Affect Taste? The Perceptual Transfer of Product Container Haptic Cues. Journal of Consumer Research, 34, 807-818. https://doi.org/10.1086/523286

[40] Krishna, A. (2006) Interaction of Senses: The Effect of Vision versus Touch on the Elongation Bias. Journal of Consumer Research, 32, 557-567.

https://doi.org/10.1086/500486

[41] Zampini, M. and Spence, C. (2004) The Role of Auditory Cues in Modulating the Perceived Crispness and Staleness of Potato Chips. Journal of Sensory Studies, 19, 347-363. https://doi.org/10.1111/j.1745-459x.2004.080403.x 
[42] Albretch, C.M., Hattula, S., Borneman, T. and Hoyer, W.D. (2016) Customer Response to Interactional Service Experience: The Role on Interaction Environment. Journal of Service Management, 27, 704-729. https://doi.org/10.1108/JOSM-07-2015-0215

[43] Menon, S. and Soman, D. (2002) Managing the Power of Curiosity for Effective Web Advertising Strategies. Journal of Advertising, 31, 1-14. https://doi.org/10.1080/00913367.2002.10673672

[44] Hill, K.M., Fombelle, P.W. and Sirianni, N.J. (2016) Shopping under the Influence of Curiosity: How Retailers Use Mystery to Drive Purchase Motivation. Journal of Business Research, 69, 1028-1034. https://doi.org/10.1016/j.jbusres.2015.08.015

[45] Scholz, J. and Smith, A.N. (2016) Augmented Reality: Designing Immersive Experiences That Maximize Consumer Engagement. Business Horizons, 59, 149-161. https://doi.org/10.1016/j.bushor.2015.10.003

[46] Javornik, A. (2016) Augmented Reality: Research Agenda for Studying the Impact of Its Media Characteristics on Consumer Behavior. Journal of Retailing and Consumer Services, 30, 252-261. https://doi.org/10.1016/j.jretconser.2016.02.004

[47] Carmigniani, J. and Furht, B. (2011) Augmented Reality: An Overview. In: Furht, B., Ed., Handbook of Augmented Reality, Springer, New York, 3-46. https://doi.org/10.1007/978-1-4614-0064-6_1

[48] Zarantonello, L. and Schmitt, B.H. (2010) Using the Brand Experience Scale to Profile Consumers and Predict Consumer Behavior. Journal of Brand Management, 17, 532-540. https://doi.org/10.1057/bm.2010.4

[49] Ferguson, R., Paulin, M. and Bergeron, J. (2010) Consumer Sociability and the Total Service Experience: Antecedents of Positive Word-of-Mouth Intentions. Journal of Service Management, 21, 25-44. https://doi.org/10.1108/09564231011025100

[50] Schmitt, B.H. (2010) Experience Marketing: Concepts, Frameworks and Consumer Insights. Foundations and Trends in Marketing, 5, 55-112. https://doi.org/10.1561/1700000027

[51] Cachero, S. and Vázquez, R. (2017) Living Positive Experiences at Store: How It Influences Shopping Experience Value and Satisfaction? Journal of Business Economics and Management, in press. http://dx.doi.org/10.3846/16111699.2017.1292311

\section{Scientific Research Publishing}

Submit or recommend next manuscript to SCIRP and we will provide best service for you:

Accepting pre-submission inquiries through Email, Facebook, LinkedIn, Twitter, etc. A wide selection of journals (inclusive of 9 subjects, more than 200 journals)

Providing 24-hour high-quality service

User-friendly online submission system

Fair and swift peer-review system

Efficient typesetting and proofreading procedure

Display of the result of downloads and visits, as well as the number of cited articles

Maximum dissemination of your research work

Submit your manuscript at: http://papersubmission.scirp.org/

Or contact ajibm@scirp.org 